\title{
Movie Induced Tourism and Its Effects on Settlements, A Literature Study
}

\author{
Urbánné Treutz Ágnes
}

PhD Student, Assistant Lecturer, Department of Marketing Management, Faculty of Economics and Social Sciences, Szent István University, Hungary

\section{Horváth Ádám}

PhD Student, Assistant Lecturer, Department of Marketing Methodology, Faculty of Economics and Social Sciences, Szent István University, Hungary

\section{Gyenge Balázs}

$\mathrm{PhD}$, Associate Professor, Department of Marketing Methodology, Faculty of Economics and Social Sciences, Szent István University, Hungary

\section{Szabó Zoltán}

PhD habil., Associate Professor, Department of Marketing, Faculty of International Management and Business, Szent István University, Hungary

\begin{abstract}
Even though movie tourism as a whole is an area that is somewhat hard to study and measure, it is one of the most interestingly developing branches of tourism, that is aiming for special consumer segments. The former being highlighted by having most related studies attempting to measure the effects of single movies, thus having a hard time establishing a general picture about the consumers that are more keen to movie induced tourism.

The aim of our literature study was to explore the main features and characteristics of movie induced tourism, which was conducted by summarizing various literary sources. The systematization of such works and approaches indicates that film tourism has numerous factors in effect concerning both the demand and supply perspective. The main purpose of this study is to explore the theoretical background of movie induced tourism and to aid in setting up the framework for later primary research. From the demand perspective, we search for the motivating factors of travelers, the possible reasons behind the popularity of visiting film related locations (the main appeals of such activities) and the criteria movies must meet to even be considered as such. Looking from the supply standpoint as well, we also seek to find out what film tourism related attractions might possible tourist destinations have, as well as how they might use these movies in their communication; what image elements or symbols are suitable for them to use in their settlement marketing.

The results of the study may be useful for further and deeper investigation (meaning primary research), especially for the supplier side of movie induced tourism; that is to gain a better understanding of the very special and diverse consumer segments and filmmakers (and the leading motivators behind their choices of choosing regions and locations to shoot), while also improving their marketing activities, communication and other means to increase the attractiveness of their locations or settlements.
\end{abstract}

Keywords: Movie induced tourism, settlement marketing, destination, cultural marketing, tourism marketing JEL Classification: M31.

(C) The Authors, 2018. This article is published with open access at Sumy State University.

\section{Introduction}

In the 21st century, cinematic medium as a whole (including movie releases as well as television shows) has taken over the lead from written literature as the cultural source with the highest impact on leisure time activities. Movies are able to create a strong emotional connection with the places seen on the silver/television screens, and they also create an opportunity for visitors to look up these places, to experience or imitate the things they have seen in the motion picture. All the while, due to the interest generated by movies and television 
shows, the number of visitations are increasing to these destinations, which may profit from the movie years or even decades after its release.

The term "film tourism" in the interpretation of Roesch (2009) stands for a subtype of tourism, where the visitors seek out places that they have seen in movies or television shows, be it during the filming (mid-production), or after its release. In his work Roesch differentiated between the places showcased on the screen (countries, settlements, spaces) and the actual film locations. In the latter's case we might further divide by differentiating the authentic "on-location" tourism from the artificial "off-location" tourism, which mostly refers to visiting tours provided by film studios on their built sets, theme parks and other events related to film tourism (like movie festivals).

While discussing movie induced tourism the main focus goes on motion picture releases, it is important to note that television shows (the "small screen" relatives of movies, that tend to evolve in similar directions) may also play a significant role in the touristic revenue of a given settlement. It is worthy to highlight the differences between the two mediums, as while movies aim to serve as a one time, limited experience for its audiences, television shows usually work with a longer period of time of reception, with often larger scaled, more complicated plot (like the popular Last of the Summer Wine, which ran in the United Kingdom between 1973 and 2010, continuously for 37 years). This results on the viewers having more time to find their identification points with the plot of the show, its characters and locations. Thus the interest towards the related regions can be maintained for longer, while the production crew also spends more time on the filming location (Beeton, 2016).

When discussing the main elements of tourism demand, we can think of leisure time, discretionary income and motivation; while among the elements of supply are the attraction or appeal of a place, infrastructure, means of transport, hospitality, accommodation and dining opportunities, entertainment and other services, prices, tourism organization, hygiene and safety (Lengyel, 1994). The term tourism destinations is coined for locations where tourism related demand appears (Michalkó, 2011), in other words it describes space with receptive capabilities or a target location for travelers (Michalkó, 2011; Panyor et al., 2011). Destination also includes the tourism related products and services that visitors might purchase in a given location. These products and services appear together as the complex destination product, and it entails all environmental and social-cultural elements, as well as leisure opportunities present in the area. All of the above essentially cumulates into the tourism experience of visitors (Panyor et al., 2011).

\section{The demand aspects of film tourism}

We can classify tourists whose main travel motivation was induced by a movie as film tourists (Gjorgievski Trpkova, 2011). Motivated and affected by various kind of movies, these travelers can be widely different based on the nature of the movie, as the separate researches done by Sulyok $(2005,2009)$ have pointed out. The foremost common points from a demographic and sociocultural standpoint tend to be high education level, relatively high income and susceptibility to culture; furthermore both the younger (Sulyok, 2009) and older (Sulyok, 2005) age groups appeared to be involved. Summarizing various studies, Irimiás (2015) emphasized the existence of a more complex, multi layered demand, highlighting the different visitor segments for the various movie releases (while we can talk about mostly 30-40 year old male groups for the Star Wars series, the locations of the 1965 The Sound of Music are more often visited by the ladies among the 20-30 age groups).

\subsection{Traveling motivations}

Exploring the motives behind people's actions is never an easy task, as Beeton (2006) has pointed it out, the correlation between the actual motivations and the ones given as a response are quite low. Numerous tourism related research has studied traveling motivations and even though the newer and newer theoretical ideas cover the topic in its fullest, they all raise further questions and newer aspects in the matter.

While the earlier researches about movie induced tourism mostly highlighted the more passive - and thus somewhat more shallow - watcher experience when they were studying the motivations of visiting movie locations, this was later switched to the more complex, personality based theories (Beeton, 2010). Maconis (2004) created the outline for another possible approach which showcases the motivations behind the demand of film tourism, the main pillars of which are the following:

- pull factors: 
- location (like landscape or the natural/cultural heritage, a point of interest that is worth visiting as it appeared in the movie),

- plot (story, genre, mood, all some kind of abstraction from the daily life, or the experience of some kind of unique fantasy),

- star (actors, directors or even the characters portrayed through the movies, like the historical figure William Wallace in the 1995 Braveheart, a movie with such a popularity that it was responsible for many foreign visitors and success for the tourism of Scotland (Gjorgievski - Trpkova, 2011),

- push factors, meaning inner motivation (like self-realization and status).

Based on the tourist types mentioned above he specified the random film tourists (whose choices were not at all influenced by the movie connection, they just happened to find themselves on a movie related location), the general film tourists (for whom movies played a role among other motivating factors, though it did not serve as the primary decision criteria), and the dedicated film tourists (who specifically sought out the locations they have seen in movies).

\subsection{The criteria for successful film tourism}

While numerous studies have implied that a major proportion of potential visitors would be likely to seek out locations they have seen in movie theatres or their television screens, it has also become more apparent that there are multiple criteria at play for the success of film tourism. It is very telling to compare the revenue of the New Zealand tourism following the success of the Lord of the Rings (a movie that is also valued as a 41 million USD advertising campaign based on the cautious calculations of the country's own analysts (New Zealand Institute of Economic Research 2002)), against such historical films as the 2000 Gladiator, or the 2004 release of Troy, where Malta provided the production location, yet was far less able to profit from the success of the otherwise blockbuster movies (Sulyok, 2009).

The first comprehensive model was created by Hudson and Ritchie (2006). This is shown with minor alterations on Figure 1., in which they attempted to determine the success factors that influence the film tourism effect of a particular movie.

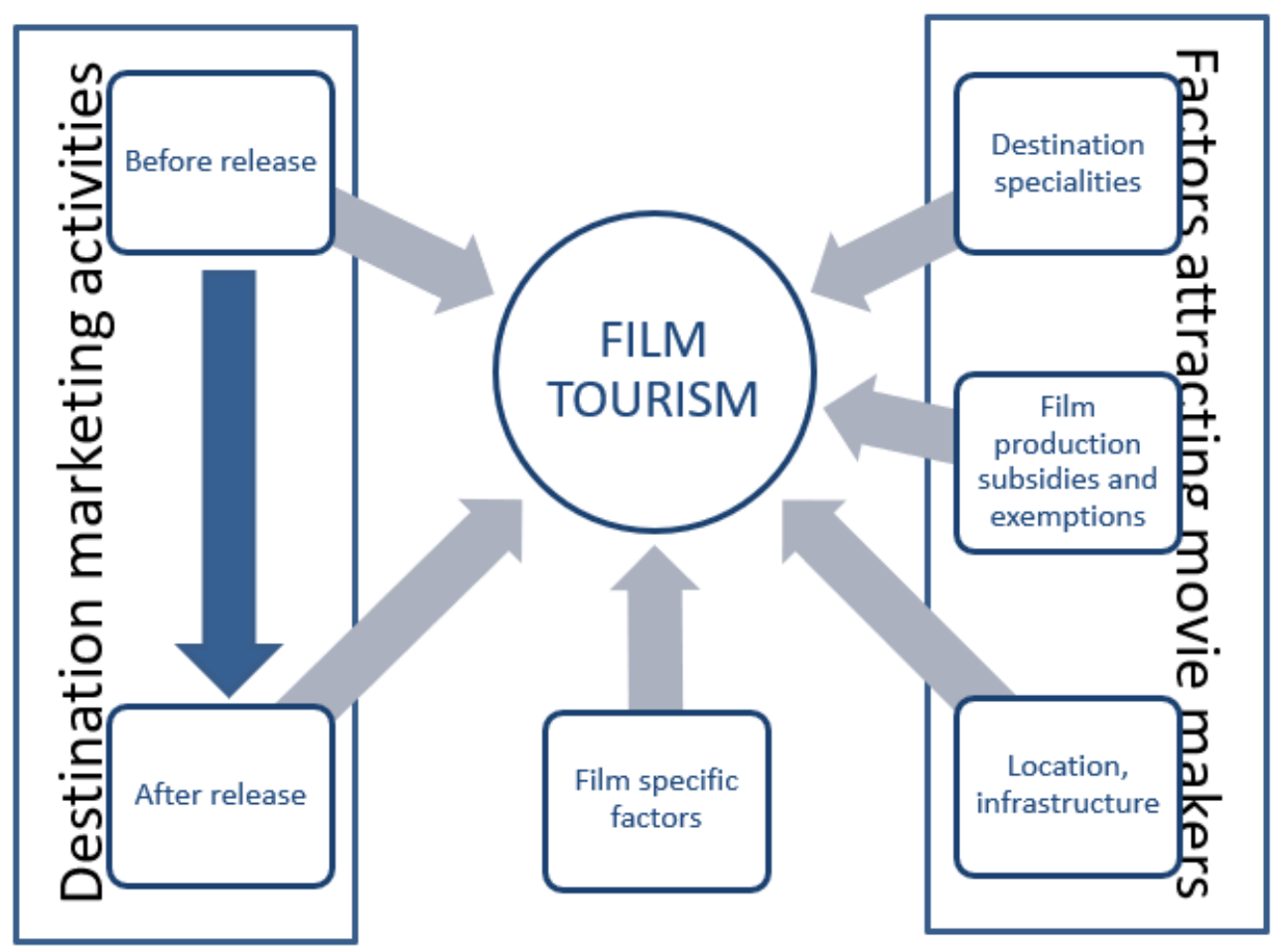

Figure 1. The success criteria of film tourism 
The five elements that determine the success potential of film tourism include the destination marketing activities. These include the incentives of the film industry's offerings - both before and after the release of the movie -, which can be used in the earliest stages of filmmaking through promoting the movie to be made and with it the locations to be featured. Examples for this would be the occasional inclusion of the location in the credit roll, the promotional footage made with the actors on the set, or nowadays even posts of the actors and crew on social sites about how well they felt in the country etc. Along the movie itself, all of these place great emphasis on the regions and settlements that serve as host to the movie as a filming location.

In addition to the above, film-specific factors are to be highlighted that also have a significant impact on the success of film tourism: such as the success of the movie, the recognition of the locations or the locations importance in the plot. Having a well embedded and easy to recognize location placement is completely in vain for movies such as the 2015 The Man from U.N.C.L.E.'s Rome or the 2007 Rush Hour 3's Paris, where these titles themselves did not garner enough audience interest. Likewise it is remarkable that while Woody Allen in his earlier movies has placed New York City in a central role (appearing as the key connecting link and cultural node for its characters), he has in the past years turned away from the Big Apple and has shifted his character-oriented stories to other American and European major cities (with a special nod to his 2011 Midnight in Paris, a movie which after its start with a three-minute city montage, keeps Paris in center stage - both visually and through its plot - until the end credits (Kovács, 2011)).

Among the other key factors are those that help to attract the attention of filmmakers to a given location; such as the specialties of the destination (uniqueness, familiarity, background functionality), various film production subsidies and exemptions (tax incentives, financial aid in the promotional budget, assisting in finding suitable filming sites) and last but not least the infrastructure of the location (available resources, including the available professionals and production studios, workshops) - whose significance is highlighted especially through business tourism.

\subsection{Movie induced business tourism}

Film related business tourism is a special form of the demand side of film tourism, which includes the travels of those looking for appropriate filming sites prior to the start of production, as well as the actual production crew's travels and staying on location (when they are able to use the available services of the tourism sector).

Film shootings can usually last for months, and this may mean years in the case of series. For example for the ever growing story aspect of the HBO show, Game of Thrones, countries like Malta, Croatia, Iceland, Morocco and Spain has joined Northern Ireland as filming locations, during its multi-season run. Therefore, the choice of location requires great care. While making these decisions, certain elements that are generally related to services of tourism are taken into account, such as the film infrastructure of a particular city, state and regional subsidies, uniqueness of the location, tax incentives and the attitude of the local population to filming (Irimiás, 2015). Almost every country in Europe offers indirect state support for film production, and Hungary is in a particularly good position, since - among other reasons - the system already works well in practice. The Hungarian film industry, which operates with four factories (Etyek, Mogyoród, Fót, Pomáz), can handle roughly two major productions at the same time, which also means the full utilization of film studios used for related post-production. The film infrastructure also accounts for the knowledge of local professionals (cinematographers, cameramen, light operators, costume designers and creators, decoration and prop designers, make-up artists), along with the history of Hungarian filmmaking, the highly regarded film oriented education and the numerous foreign productions made in the country (Muhi, 2010). The use of local professionals is especially important for its cost-effective nature, as travel arrangements and residence calls for a far lower budget this way. In addition to the above, the issue of convenience - which is also a significant factor of decision-making: higher ups in the production hierarchy (meaning the producers, the director(s) and the actors with greater star power) must be convinced that the particular settlement will meet all of their demands at a high standard (Irimiás, 2015).

Somewhere between professional and leisure tourism, there are various film festivals, which serve as an excellent start point for launching news around the release of the movie (both by appearing at the festival and the subsequent critical reviews about it). For movie production in many countries these occasions provide the best opportunities to stand out. These festivals also make it possible for independent movies to enter the movie theatres, as many distributors will take this opportunity to measure them and their impact on the audience often resulting in an immediate agreement (or additional funding for further refinement, reshoot, music selection etc.). Just the North American region in itself provides home for nearly 800 multi-day film festivals 
annually (of which the biggest and most commonly known are the Sundance and the Toronto International Film Festival). Having such a large amount of film festivals is also influenced by the organizing regions and settlements who also base many of their artistic, cultural programs and tourism incentives on them (Marich, 2009).

\section{The supply aspects of film tourism}

As Irimiás (2015) has claimed, film-touristic attraction is any conceivable (objectified) and intangible (intellectual) element that is related to the filming, production or distribution aspect of movies or television programs.

Thus the supply elements of film tourism are (Irimiás, 2015):

- filming site generated film tourism (on-location),

- profit oriented commercial attractions,

- stand in locations - runaway productions,

- film production related film tourism,

- unique movie events,

- traveling from the armchair.

The attraction of film tourism to filming sites may be the location itself. In this case the movie might be the source of the primary motivation, it may be a part of a greater travel experience, or a destination for a sort of pilgrimage, which would imply a strong emotional attachment to the related movie. An example for this would be New Zealand, which was the location of the aforementioned Lord of the Rings trilogy and later The Hobbit movies. Similar attraction might be induced by the home of movie stars or other filming locations that revive past times in the minds of visitors (like visiting the building in New York City which was emblematic for hosting one of the most acclaimed situational comedies of the 90s, Friends).

Profit oriented commercial attractions include special filming sites that are located in private areas; movie themed tourist trips; and also the superstructure associated with the movie (the full range of offerings of the venue, covering accommodation, catering and other services provided for tourists).

Stand in locations are attractions that are merely "pretend" sites, that is to say, the filming was not done where the plot of the movie or series takes place. Thus, for example in the 2000 Hungarian movie Meseautó, even though the story took place in the castle of Visegrád, filming was made in the castle of Parádsasvár.

Film production related film tourism includes guided tours of various film studios (such as the ones taking place in Warner Bros. Studio or the Hungarian Korda Studio) and movie theme parks (non-film-making film studios that meet the needs of consumers), like The Movie Park located in Bottrop-Kirchhellen, Germany.

Unique film events reinforce the reputation and attractiveness of cities where film festivals (Cannes) and movie premiers (London) are taking place.

The experience of traveling from the armchair is given by movies, shows and documentaries based on traveling (like the Hungarian made 2014 movie series, Magyarország madártávlatból featuring a bird's eye view on the country), or by gastronomy based road movies, like the 2014 Chef (Irimiás, 2015).

The emphasis on the attractiveness of a given area is very important, as society tends to read less and less, so the role of audiovisual media is becoming more and more prevalent in harboring interest towards a given destination (Sulyok, 2009). Previous publications (such as Hudson and Ritchie, 2006; Irimiás, 2015) have summed up the locations and attractions of several foreign films, in the following we have summarized some of the attractions from movies filmed in Hungary, which are shown in Table 1.

Table 1. Filming sites and their attractions in Hungary

\begin{tabular}{|l|l|l|}
\hline \multicolumn{1}{|c|}{ Movie } & \multicolumn{1}{|c|}{ Filming site } & \multicolumn{1}{c|}{$\begin{array}{c}\text { Destination attraction highlighted in the } \\
\text { movie }\end{array}$} \\
\hline Meseautó (1934) & Budapest, Lillafüred & $\begin{array}{l}\text { Lillafüred: Lake Hámori, Hunguest Hotel } \\
\text { Palota }\end{array}$ \\
\hline Liliomfi (1954) & Badacsony & Szegedy Róza Ház, szölő, bor, Balaton \\
\hline A Tenkes kapitánya (1963) & Tenkes-hegy, Siklós & Natural environment, castle \\
\hline Tüskevár (1967) & Kis-Balaton & Natural environment \\
\hline
\end{tabular}


Table 1 (cont.). Filming sites and their attractions in Hungary

\begin{tabular}{|l|l|l|}
\hline \multicolumn{1}{|c|}{ Movie } & \multicolumn{1}{|c|}{ Filming site } & \multicolumn{1}{c|}{$\begin{array}{c}\text { Destination attraction highlighted in the } \\
\text { movie }\end{array}$} \\
\hline Egri csillagok (1968) & Pilisborosjenö & Natural environment, castle \\
\hline Rózsa Sándor (1971) & Hortobágy & Natural environment, Great Plain \\
\hline Lutra (1986) & Lillafüred & Trout lake \\
\hline Szomszédok (1987) & Budapest & Gazdagrét residential \\
\hline Au Pair (1999) & Gödöllö, Szentendre, Budapest & $\begin{array}{l}\text { Gödöllö: Royal Palace, Szentendre: pedes- } \\
\text { trian streets, Budapest: Vajdahunyad castle }\end{array}$ \\
\hline Üvegtigris (2001) & Garancs-tó & Lake, buffet-vehicle \\
\hline Tibor vagyok, de hódítani akarok (2006) & Balatonfüred & Balaton, Flamingó Hotel \\
\hline S.O.S. Szerelem (2007) & Kutas-Kozmapuszta & Hertelendy castle \\
\hline & & $\begin{array}{l}\text { Architecture values (Palace of the Adria, } \\
\text { Budapest University of Technology and } \\
\text { Economics, Festetich Palace, Gundel Res- } \\
\text { taurant, Opera, Museum of Applied Arts, } \\
\text { Museum of Ethnography) }\end{array}$ \\
\hline Drakula (2013) & Budapest & Natural environment \\
\hline A mi kis falunk (2017) & & Pilisszentlélek \\
\hline
\end{tabular}

Source: Own elaboration (2018) based on Irimiás (2015).

With regard to the film tourism supply, it is worth examining how much of it the given destination generates through the attraction, how much time can the tourist spend on the location. Based on the duration of the trip, we can distinguish between daily (or excursion) tourism (which takes 24 or less hours, without spending the night), the subject of which is the hiker; and staying tourism (above 24 hours, at least one night spent), the subject of which is tourist (Puczkó-Rácz, 2001).

Accordingly, we can sort the city of Metropolis (Illinois, USA) as a movie related excursion tourism place, which is basically a stand in location as the 1978 Superman movie was not filmed locally, but according to the plot Clark Kent was working in the Daily Planet newspaper magazine based in Metropolis.

Citizens of Metropolis are still proud of the fact that the film is linked to their city, and this is reflected in the Superman statue on the main square of the city and also in the form of the Superman Museum. However, these film tourism attractions do not provide more than one day's worth of sightseeing and related experience for the consumer (Figure 2).

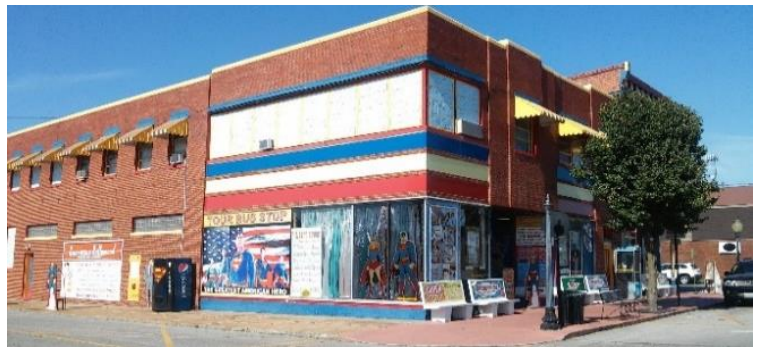

Figure 2. Superman Museum of Metropolis

Source: Urbánné Treutz Ágnes, 2016.

More than one day's worth of leisure might be provided by settlements where several movies where filmed, or where one may visit more than one filming site or film studio. In addition, thematic tours may also generate longer time spending in a particular settlement. The thematic tour cover some artificial or natural attractions related to the subject, which are available in different ways of transport (Puczkó-Rácz, 2011).

In terms of geographical coverage, we can distinguish between four types of thematic trips:

- local/urban trips,

- regional trips,

- national trips,

- international trips. 
The attractions offered by the thematic trips have been embraced by several companies / settlements, which organize movie tours and events for those interested. An example for this is the "Sex and the City Hotspots" tour organized by the Turner Classic Movies channel, where you can track the protagonist of the Sex and the City series, visiting over 40 locations where Carrie appeared in the series. The theme of the thematic journey can not only be about a specific film, but also about film production in general. Such are the "TCM classic movie tours" in New York, where tourists can visit famous movie locations (like the Empire State Building), thus discovering the sights of the city, interconnected with movie experiences (ticmate.com, 2018). All of the above can be sorted in the group of urban thematic trips.

There are several examples of regional thematic trips in the United Kingdom, where through the offers announced by British Movie Tours it is possible to visit the various filming sites of the Downton Abbey series. This includes sites all over the countryside around London and Oxfordshire, with the ability to take part in two-day tours as well (britmovietours.com, 2018).

Brit Movie Tours also offers nationwide thematic film tours. Fans of the series Doctor Who for example can take part in a three-day trip, with the opportunity to visit the series-related sites in both the UK and Scotland (britmovietours.com, 2018).

An international film related thematic trip can be organized based on any film whose locations (or stand in locations) of filming are spread out over different countries. One example is the 1997 Fools Rush In, which takes place in the United States of America (Las Vegas, Grand Canyon, Hoover Dam, New York) and Mexico (Tamazula).

The advantage of thematic trips is that they provide opportunities for different settlements to build and maintain continuous cooperation. It is also important to mention that in addition to linking individual sites (according to a particular structure, in these examples through motion picture), they may inflict a multiplier effect on other additional services (after finishing a thematic tour, tourists can, for example, take advantage of the catering and accommodation services available in a given settlement) (Irimiás, 2015).

\section{The relation between film tourism and settlement marketing}

As we already mentioned before, film tourism can affect both the economic and social life of the settlements. It is important to take both the local residents' reactions to increased tourism (attitude towards tourists, increasing number of tourists, its impact on the environment) and the economic utility generated by film tourism into account. The purpose of settlement marketing is to increase the quality of life and standard of living of a given settlement, all the while adequately satisfying the needs of the target groups. The three main target groups of settlement marketing are local residents, entrepreneurs and tourists, so it is very important to develop the right harmony between these target groups. Settlements must consider both the positive and negative effects generated by film tourism.

According to Kozma (2002) and Puczko-Rácz (2011), the following effects can be defined for any settlement (which we will further clarify below in reference to film tourism):

- economic effect,

- tourism-trade effect,

- socio-cultural effect,

- physical effect:

○ natural environment,

○ built environment.

The positive economic effect of movie induced tourism can be seen in purchases and expenses of visitors, film tourists, which may generate direct revenue for people living in the settlement. Through the various taxes, central and local government budgets also benefit from these revenues. Products appearing in tourism related commerce can usually be sold at a higher price than the export price, resulting in a higher overall revenue. This is mainly related to souvenirs, as their nature gives the product's value an emotional surplus, which will be appreciated in the tourist's home country as well (while it could be a less attractive purchase as an imported product on its own). Additionally the need to provide for movie induced tourism induces an increase in the number of jobs, which reduces local unemployment. The catalyst aspect of film tourism can have an important positive economic impact, which may lead to an improvement in the quality of life though economic growth. If the appeal level of a particular film tourism attraction is significant, then the development of the settlement 
and an increase in its competitiveness can be achieved. Negative economic impact can be attributed to the lossmaking operation of film tourism attractions (the maintenance of movie theme parks or organized movie tours can be quite costly for example) and higher prices (such as accommodation, catering, etc.) appearing due to the increased demand.

The economic effect is closely linked with the tourism-trade effect of film tourism. Having some sort of media exposure is a positive effect that attracts film tourism and helps in placing a given destination to the mental map of consumers. This may result in a visit, and in case of satisfaction, a possible return to the settlement. Negative effect may originate from an unexpected, adverse event that may result in a negative image of a specific area (such as a terrorist act).

The socio-cultural effect may be reflected in changes in the quality of life of the people affected (local residents, entrepreneurs), having an increase of recreational opportunities for local residents (for example they may also take part in a movie tour), and the blossoming of public-private partnerships (PPPs). All the while a common area of interest may arise between certain social groups (like volunteers for example) and the film tourism organizations. The development of a film tourism organization in a given area entails changing the image of a given place, and also the possible integration of local residents (some may join tourism, if they feel up to it). The latter may also act as a negative impact if it shatters the existing local community. Another negative aspect could be that the presence of a greater number of film tourists could have an adverse impact on the everyday life of the local people, who might even get into conflicts with the outside visitors.

Within the physical effects we can think of the impact of film tourism on the natural and constructed environment. The beneficial effect on the built environment can be perceived when the infrastructure is being developed and deteriorated neighborhoods get renewed as a result of tourism. It can have an unfavorable impact on the built environment if the buildings become obsolete during use, or if they are amortized through damage or visual contamination (when the particular tourist attraction does not fit into the mood and style of the existing space). Negative effects in the natural environment can be the overload of the environment (through overcrowding, increasing waste loads and untended garbage, increasing air and noise pollution, etc.), ecological damage, landscape destruction (Kozma, 2002, Puczkó-Rácz, 2011).

It should be mentioned for the physical effects of film tourism, that the built environment of a settlement has an impact on the fantasy world that the movies are trying to create - thus aiding the association of dreams and images with certain places. Some settlements trigger unique emotional reactions from visitors and also shape the values and lifestyles of those living there. Some locations may have a symbolic significance, where icons can also be used to identify the names of specific settlements. This can be an empty space (like St. Peter Square in the Vatican) or a building (such as the Louvre in Paris), which are all part of the "spirit of the place". These icons are also commonly used during in movies as well, as they help to draw attention to the natural and constructed heritage of a given town. Then they can be placed on the mental map of the consumer, as well as a possible destination on the visitor's bucket list (such as the Colosseum from the 2000 Gladiator film).

These movies also create associations in the consumers for the given locations, which shapes their opinion about the related settlement (like the 2008 Twilight which paints a myserious and ancient picture about the town of Volterra in the viewer) and is also able to change it (Irimiás, 2015). Thus, movies may influence the image of settlements. Based on Kotler et al. (1993) we can distinguish between locations with positive-, negative-, controversial-, mixed- and weak image.

A location with a positive image might induce the consumer to have positive attitude towards it. The 1955 Sissi builds a positive image for the island of Madeira, where they not only showcase the natural environment's beauty of the island, but they also take part in the positive outcome of the movie's plot (the queen recovers from her illness). Having a negative image might induce a negative attitude for the consumers. Examples for negative representations entail Albania in the 1997 Wag the Dog and Iran in the 1991 Not Without My Daughter. In controversial imaged places, different ethnic groups might have different views. Historical events often result in negative images in some consumers, while others might have a positive intake due to only experiencing them through the portrayal of movies, thus forming a positive attitude towards the location. This was the case with the site of the D-day landing in Normandy during the Second World War, which took hundreds of thousands of lives, which after the 1998 release of Saving private Ryan had a major influx of - mostly american - tourists (Hughes, 1998) (Sulyok, 2009). A similar change of opinion and increase of visitors can be expected as an aftermath of the similarly themed 2017 release of Dunkirk and its success. Another noteworthy example here would be the 1997 Titanic which while portraying an international tragedy also managed to give another rise 
of interest to ocean cruises and recreational boats. Locations with mixed image have both positive and negative factors influencing them. Great examples for this phenomenon are the movies that portray both the highs and lows of everyday life in India, like the 2008 Slumdog Millionaire or the 2016 Lion (which was based on true events). Weak imaged locations have no associated attitudes. These are less known places that have yet to enter the public domain (Kotler et al., 1993). An example for this weak image is the Hungarian series A mi kis falunk which brought the name of Pilisszentlélek under the spotlight and started to build the positive image of the settlement. The interest of people and the process of entering the public domain can be tracked by the internet search statistics, though the series used the fictional name of "Pajkaszeg", many consumers were interested in the original name of the settlement as well. Figure 3 shows that almost a year before the start of the series (2017.02.02), there was almost no search for the term "Pilisszentlélek". The high values represent the periods of time when the series was running its then current seasons.

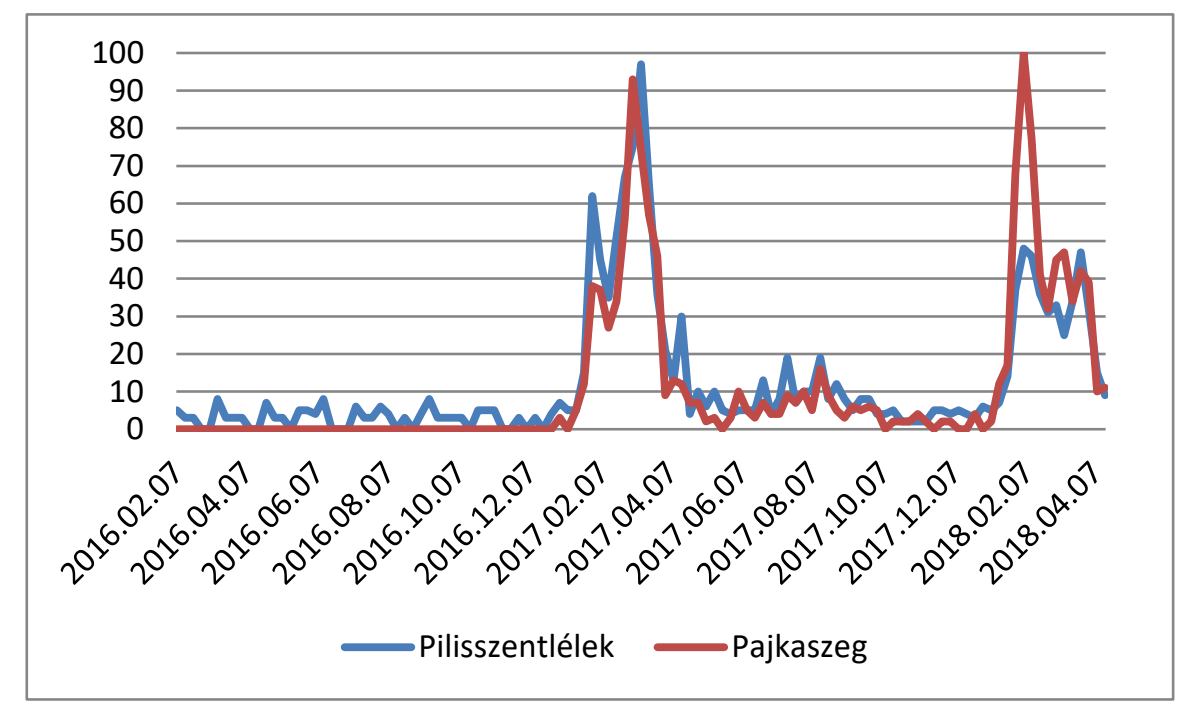

Figure 3. Search history statistics for the terms "Pilisszentlélek" and "Pajkaszeg" between 2016.02.07 and 2018.04.15.

Source: trends.google.com, 2018.

Elements that contribute to creating the image are the picture's composition, the camera settings or the choice of colors. These all convey such emotional message to the consumer that they are able to connect with the visual elements in the movie (environment, landscape). Decoding the resulting image they are searching for associations, drawing conclusions and forming opinions, thus creating the image about that particular location (Irimiás, 2015).

The purpose of a locations development strategy is of the create adequate supply for the consumers, to build a uniform image with the involvement of local people, to ease on the accessibility of the place, to reach the right target market and to strengthen territorial identity, thus emphasizing its uniqueness (Irimiás, 2015). A movie can have an effect on the life of a settlement, it can be incorporated into its everyday life. This was the case with the "Superman fame" living on in Metropolis. An event is held annually that is connected to the movie, when every Superman fan visits the town for the "Superman Celebration", which goes on for four days. During this vendors are selling food, hand-crafted products and comic books, thus creating economic profit for the town. All the while they also have auctions, discussion forums, costume contest and other events during the long weekend. The movies influence can also be caught in the naming of the local newspaper, which is "The Metropolis Planet", mimicking the fictional "The Daily Planet" newspaper of the movie (supermancelebration.net).

\section{Conclusions}

In our study we looked at the demand side of film tourism, including the main, commonly shared features of the possible target segments, as well as the possible motivations tied to movie induced tourism. We have also summarized the key criteria to successful film tourism, among which highlighting the destination marketing activities that fall into the supplier territory and the features that help creating interest for the filmmakers and also help define movie related business tourism. Subsequently we also described the supply side of film tourism, the key points of which are the different types of (supposed or real) filming sites, the attractiveness of 
locations or their involvement in the marketing of different regions and settlements (highlighting economic, tourism-trade, socio-cultural and physical effects).

As the popularity of motion picture is likely to flourish, film tourism is still ahead of further great achievements and countless challenges in the future. From this point of view, the competitive orientation of tourism is of particular importance, where the ever-increasing service level and professionalism are treated as a basic requirement for success. Further and deeper investigation in the area may seem desirable, especially if the suppliers of film tourism wish to get a better understanding of their diverse consumer segments.

In connection with the scope of the topic, several aspects can be pursued in creating relevant research in the future: the viewpoint of local residents, tourists, settlement leaders and filmmakers. In our primary research the first exploratory step would be to conduct a qualitative data collection: to get a more detailed understanding of the supply side of movie induced tourism, the opinion of settlement leaders (in a series of qualitative interviews) can help highlight the strengths of the settlement, utilize its idle resources, eliminate its weaknesses, exploit opportunities and mitigate the threats. By seeking out filmmakers on the demand side, we can measure their exact needs towards their filming locations (services, infrastructure etc.), that settlements can then aim to meet.

As a second phase, local residents (appearing on the service provider side) are worthy of quantitative research to assess their attitudes towards film tourism in their environment (thus further aiding the settlements to strengthen the positive features while negating the negative effects). In order to create and maintain a film tourism attraction in a settlement, it is important to keep the needs and wants of the consumers in mind. This information can be obtained by surveying tourists of various thematic tours and trips as well as people who are fond of movies in general (e.g. visitors of movie theatres), thus forming a potential target group to study the demand side of movie induced tourism in a quantitative way.

\section{References}

1. Beeton, S. (2006). Understanding Film-Induced Tourism. Tourism Analysis, 11, 181-188.

2. Beeton, S. (2016). Film-Induced Tourism (2nd ed.). Channel View Publications, Bristol. 13-14 p.

3. Gjorgievski, M., Trpkova, M. (2011). Movie induced tourism: A new tourism phenomenon. UTMS Journal of Economics, 3(1), 97-104.

4. Hudson, S., Ritchie, J. R. (2006). Promoting Destinations via Film Tourism: An Empirical Identification of Supporting Marketing Initiatives. Journal of Travel Research, 44(4), 387-396.

5. Hughes, J. (1998). Private Ryan fans invade D-Day sites. Independent. Retrieved from: https://www.independent.co.uk/news/private-ryan-fans-invade-d-day-sites-1199419.html. Accessed: 2018.04.21.

6. Irimiás, A. (2015). Filmturizmus. Budapest, Akadémiai Kiadó. 235 p.

7. Kotler, P., Haider, D.H., Rein, I. (1993). Marketing places: attracting investment, industry and tourism to cities, states and nations. New York, Macmillan. 388 p.

8. Kovács, K. (2011). Kultúrturizmus (Éjfélkor Párizsban). Filmvilág, 54(11), 51-51.

9. Kozma, G. (2002). Terület- és településmarketing: geográfus és földrajz tanár szakos hallgatók számára. Debrecen, Kossuth Egyetemi Kiadó, 155 p.

10. Lengyel, M. (1994). A turizmus általános elmélete. Budapest, KIT Képzőmüvészeti Kiadó. 297 p.

11. Macionis, N. (2004). Understanding the film-induced tourist. In. Frost, W., Croy, G., Beeton, S. (szerk.) International Tourism and Media Conference Proceedings. Berwick, Monash University Tourism Research Unit, 86-97 p.

12. Marich, R. (2009). Marketing to Moviegoers: A Handbook of Strategies and Tactics (2nd ed.). Carbondale, IL., Southern Illinois University Press. 256 p.

13. Michalkó, G. (2011). A turizmuselmélet alapjai. Székesfehérvár, Kodolányi János Főiskola. 224 p.

14. Michalkó, G. (2012). Turizmológia. Budapest, Akadémiai Kiadó. 266 p.

15. Morgan, N., Pritchard, A., Pride, R. (2004). Destination branding: creating the unique destination proposition. Oxford, Elsevier Ltd. 314 p.

16. Muhi, K. (2010). Tiszta Amerika (Magyar filmipar). Filmvilág, 53(3), 4-7.

17. New Zealand Institute of Economic Research (2002). Scoping the Lasting Effects of The Lord of the Rings. A Report to the New Zealand Film Comission. Thorndon, New Zealand Institute of Economic Research.

18. Panyor, Á., Győriné, Kiss E., Hekliné, Herbály K. (2011). Desztináció és marketing menedzsment. Keszthely. $189 \mathrm{p}$.

19. Puczkó, L., Rácz T. (2001). A turizmus hatásai. Budapest, Aula Kiadó. 482 p. 
20. Puczkó, L., Rácz T. (2011). Az attrakciótól az élményig. Budapest, Akadémiai Kiadó.

21. Roesch, S. (2009). The experiences of film location tourists. Bristol, Channel View Publications.

22. Sulyok, J. (2005). Kulturális turizmus az európai városokban. Turizmus Bulletin, 3, 18-29.

23. Sulyok, J. (2009). Filmturizmus, avagy a filmekben rejlö lehetőségek a turisztikai desztinációk számára. Turizmus Bulletin, 13(1), 34-39.

\section{Online sources}

1. Brit Movie Tours: Doctor Who Tour of Wales and England [Unofficial]. https://britmovietours.com/bookings/doctor-who-tour-of-england-and-wales/ Accessed: 2018.04.19.

2. Brit Movie Tours: Downton Abbey Town and Country Filming Locations Tour. https://britmovietours.com/bookings/downton-abbey-tour-film-locations/ Accessed: 2018.04.19.

3. Google Trends comparison for Pilisszentlélek and Pajkaszeg. https://trends.google.com/trends/explore? date=2016-02-02\%202018-04-19\&q=Pilisszent1\%C3\%A9lek,Pajkaszeg Accessed: 2018.04.19.

4. 40th Annual Superman Celebration. https://www.supermancelebration.net/ Accessed: 2018.04.19.

5. Ticmate TCM Classic Film Tour. https://www.ticmate.com/p/12859/tcm-classic-film-tour Accessed: 2018.04.19.

6. Ticmate Sex and the City Hotspots. https://www.ticmate.com/p/2401/sex-and-the-city-hotspots Accessed: 2018.04.19. 